\title{
Non-linearity of the contact layer between elements joined in a multi-bolted connection and the preload of the bolts
}

\begin{abstract}
The paper presents modeling and calculations of multi-bolted connections at the assembly stage on an example of the engine cylinder head-block connection. The physical model of the connection was introduced as a combination of three subsystems: the set of bolts, the joined element and the contact layer between the joined element and the rigid support. The finite element method (FEM) was used for the modeling. Bolts were replaced with hybrid elements. The joined element was modeled with spatial finite elements. The Winkler model of the contact layer has been taken into consideration. The truth of the theorem has been examined, according to which non-linearity of the contact layer has a negligible impact on the final values of the bolt forces in the case of sequential preloading of the multi-bolted connection. The results of the calculations of a selected multi-bolted connection have been compared with the experimental results.
\end{abstract}

Key words: multi-bolted connection, engine cylinder head, engine block, assembly

\section{Nieliniowość warstwy stykowej między elementami lączonymi w połączeniu wielośrubowym a napięcie wstępne śrub}

\begin{abstract}
Przedstawiono modelowanie i obliczenia połaczeń wielośrubowych na etapie montażu, na przykładzie połaczenia głowicy z blokiem silnika. Wprowadzono model fizyczny połaczenia zbudowany z trzech podukładów: zbioru śrub, elementu taczonego $i$ warstwy stykowej między elementem tączonym a nieodksztatcalnq ostoja. Do modelowania wykorzystano metodę elementów skończonych (MES). Śruby zastapiono elementami hybrydowymi. Element łaczony zamodelowano za pomoca przestrzennych elementów skończonych. Warstwe stykowa potraktowano jako ciało Winklera. Zbadano prawdziwość tezy, wedtug której nieliniowość warstwy stykowej ma znikomy wptyw na końcowe wartości sił w śrubach w przypadku połaczenia wielośrubowego napinanego wstępnie kolejno dokręcanymi śrubami. Wyniki obliczeń wybranego połaczenia wielośrubowego porównano z wynikami badań doświadczalnych.
\end{abstract}

Słowa kluczowe: połaczenie wielośrubowe, głowica, blok silnika, montaż

\section{Introduction}

Multi-bolted connections (composed of many objects remaining in contact) are treated as non-linear systems in the calculations. The source of this non-linearity are, for example, gaskets or washers often used as additional intermediate elements in this type of connections [14, 15].

In many practical applications multi-bolted connections are designed as preloaded joints. With introduction of the preload in bolts the reliability of the connection during its operation significantly increases. This concerns, for example, multi-bolted connections between the engine cylinder head and the engine block $[10,13,16]$.

Engine cylinder head-block connections are most often analyzed using the finite element method [1]. In the subject literature, the following models of the connection can be found:

a) plain models $[2,6]$,

b) spatial models $[3,4,5,12]$.

These models are used to determine:

a) the impact of thermal loads on the retention of the preload of bolts [2],

b) the relation between the preload and fatigue crack propagation in bolts [6],

c) fatigue strength of the gasket and bolts [3],

d) the distribution of stress [4] or temperature [5] inside the engine cylinder head,

\section{Wprowadzenie}

Połączenia wielośrubowe, czyli konstrukcje złożone $\mathrm{z}$ wielu stykających się ze sobą elementów, w obliczeniach traktuje się jako układy nieliniowe. Źródłem tej nieliniowości są m.in. uszczelki lub podkładki często stosowane jako elementy pośrednie $\mathrm{w}$ tego typu połączeniach $[14,15]$.

$\mathrm{W}$ wielu praktycznych zastosowaniach połączenia wielośrubowe projektuje się jako układy napięte wstępnie. Dzięki wprowadzeniu napięcia wstępnego w śrubach zwiększa się niezawodność danego połączenia podczas jego eksploatacji. Dotyczy to na przykład połączeń wielośrubowych między głowicą a blokiem silnika $[10,13,16]$.

Połączenia głowicy z blokiem silnika najczęściej analizuje się przy użyciu metody elementów skończonych [1]. W literaturze dotyczącej tego tematu stosuje się następujące modele połączeń:

a) płaskie $[2,6]$,

b) przestrzenne $[3,4,5,12]$.

Modele te wykorzystuje się w celu ustalenia:

a) wpływu obciążeń termicznych na utrzymanie wartości napięcia wstępnego w śrubach [2],

b) zależności między napięciem wstępnym a propagacją pęknięcia zmęczeniowego w śrubach [6],

c) wytrzymałości zmęczeniowej uszczelki głowicy i śrub [3],

d) map naprężeń [4] lub temperatur [5] wewnątrz głowicy, 
e) the distribution of contact pressure on the gasket [12].

In the considered example of the multi-bolted connection between the engine cylinder head and the engine block, the following main components can be distinguished:

a) the engine cylinder head as a flexible joined element,

b) the engine block as a rigid support,

c) the contact layer between joined elements,

d) the set of bolts.

Modeling multi-bolted connections for which it can be assumed so introduced the division of their components is presented in [7]. In the developed multi-bolted connection model, it is assumed that:

a) the bolt model can be represented as a model, wherein the plain part of the bolt is modeled as a beam and its head as a rigid element [8],

b) bolts are tightened by preloads normal to the contact surface between the joined elements,

c) the flexible joined element is modeled with spatial finite elements,

d) the contact layer between the joined elements is treated as the nonlinear Winkler elastic foundation model.

The assembly process of the multi-bolted connection is conducted by sequentially tightening of the bolts. This incremental process is also related to increasingly complete clamping of the contact layer between the joined elements. As a result, during the assembly process, the normal characteristics of the contact layer becomes close to linear. The aim of this study is demonstrating such a phenomenon based on a model alternative to the model described in [7], in which the linear model of the contact layer between the joined elements is introduced.

Modeling and calculations of the multi-bolted connection were performed using the Midas NFX 2014 finite element software. The results of numerical simulations have been compared with the experimental results shown in [9].

\section{Physical model of the multi-bolted connection}

The idea of the modeling method of multi-bolted connections has been presented in [7]. The model of the connection is based on a flexible flange element that is fastened to a rigid support by means of a set of $\mathrm{k}$ bolts (see Fig. 1). Bolts are modeled as elements composed of the flexible plain part of the bolt and the rigid head. The stiffness of the i-th bolt's model $c_{y i}$ (for $i=1,2,3, \ldots, k$ ) is defined as stiffness of the beam replacing the plain part of the real bolt.

Between the joined elements (the flexible flange element and the rigid support) the Winkler elastic foundation model [11] is introduced. The contact layer model is described by means of 1 one-sided linear spring elements with stiffness $c_{z j}$ (Fig. 1b). It is defined by the following relationship:

$$
R_{j}=A_{j} \cdot f\left(u_{j}\right)
$$

where: $R_{i}-$ force in the center of the $j$-th elementary contact area (for $\mathrm{j}=1,2,3, \ldots, 1) ; \mathrm{A}_{\mathrm{i}}-\mathrm{j}$-th elementary contact area; $u_{\mathrm{j}}$ - deformation of the $\mathrm{j}$-th linear spring element.

The equation of the system equilibrium can be written as: e) rozkładu nacisków kontaktowych na powierzchni uszczelki głowicy [12].

$\mathrm{W}$ rozpatrywanym przykładzie połączenia wielośrubowego między głowicą a blokiem silnika można wydzielić cztery główne składniki:

a) głowicę jako odkształcalny element łączony,

b) blok silnika jako nieodkształcalną ostoję,

c) warstwę stykową między elementami łączonymi,

d) zbiór śrub.

Modelowaniu połączeń, dla których można przyjąc tak wprowadzony podział ich elementów składowych poświęcono pracę [7]. W opracowanym modelu połączenia:

a) przyjęto hybrydowy model śruby, złożony z odkształcalnego trzpienia i nieodkształcalnego łba [8],

b) śruby napinano siłami normalnymi do powierzchni styku łączonych elementów,

c) element łączony zamodelowano za pomocą przestrzennych elementów skończonych,

d) warstwę stykową między elementami łączonymi potraktowano jako nieliniowe ciało Winklera.

Prowadzenie procesu montażu połączenia wielośrubowego polega na stopniowym dokręcaniu kolejnych śrub. Każdorazowo ten stopniowy montaż połączenia związany jest również ze stopniowym, ale coraz pełniejszym, zaciskaniem warstwy stykowej między łączonymi elementami. W efekcie, podczas prowadzonego procesu montażu połączenia, normalna charakterystyka sztywnościowa warstwy stykowej między elementami łączonymi staje się coraz bardziej liniowa. Celem pracy jest wykazanie takiego zjawiska na podstawie modelu połączenia wielośrubowego alternatywnego do modelu opisanego wyżej [7], w którym przyjęto liniowy model warstwy stykowej między łączonymi elementami.

Modelowanie i obliczenia połączenia wielośrubowego zrealizowano przy zastosowaniu metody elementów skończonych - w programie Midas NFX 2014. Wyniki symulacji komputerowych porównano z wynikami badań doświadczalnych [9].

\section{Model fizyczny połączenia wielośrubowego}

Idea sposobu modelowania połączenia wielośrubowego została zaprezentowana w pracy [7]. Model połączenia utworzony jest z odkształcalnego kołnierza, przykręcanego do nieodkształcalnej ostoi za pomocą zbioru k śrub (rys. 1). Śruby modeluje się jako elementy złożone z odkształcalnego trzpienia - belki i nieodkształcalnego łba. Sztywność pojedynczej śruby $\mathrm{c}_{\mathrm{yi}}(\mathrm{dla} \mathrm{i}=1,2,3, \ldots, \mathrm{k})$ określono jako sztywność belki zastępującej trzpień śruby.

Pomiędzy elementy łączone (odkształcalny kołnierz i nieodkształcalną ostoję) wprowadzono umowną warstwę stykową typu winklerowskiego [11]. Warstwę stykową opisano zbiorem 1 jednostronnych sprężyn liniowych o sztywności $\mathrm{c}_{\mathrm{zj}}$ (rys. 1b). Zdefiniowano ją za pomocą charakterystyki (1), gdzie: $R_{j}$ - siła zaczepiona w środku ciężkości j-tej elementarnej powierzchni styku (dla j $=1,2,3, \ldots, 1) ; A_{j}$ - pole j-tej elementarnej powierzchni styku; $u_{j}-$ przemieszczenie $j$-tej sprężyny liniowej.

Równanie równowagi układu może zostać zapisane w postaci (2), gdzie: $\mathbf{K}$ - macierz sztywności; $\mathbf{q}$ - wektor 
a)

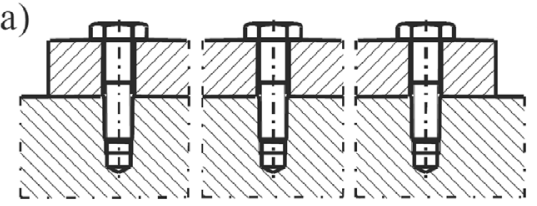

c)

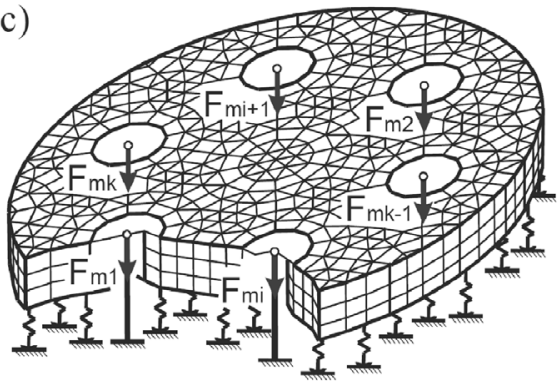

Fig. 1. Multi-bolted connection: a) diagram of the joint, b) description of the spring properties of the joint elements, c) FE-model of the joint

Rys. 1. Połaczenie wielośrubowe: a) schemat, b) opis sprężystych właściwości elementów połaczenia, c) model w konwencji MES

\section{$\mathbf{K} \cdot \mathbf{q}=\mathbf{p}$}

where: $\mathbf{K}$ - stiffness matrix; $\mathbf{q}$ - displacements vector; $\mathbf{p}$ loads vector composed of preloads $\mathrm{F}_{\mathrm{mi}}$ (see Fig. 1c).

The generating procedure of the stiffness matrix $\mathbf{K}$ has been specified in [7]. Adopting the division of the connection into three subsystems ( $\mathbf{B}$ - the set of bolts, $\mathbf{F}$ - the joined element model, $\mathbf{C}$ - the linear Winkler model of the contact layer), the equation (2) can be presented in the form:

$$
\left[\begin{array}{ccc}
\mathbf{K}_{\mathrm{BB}} & \mathbf{K}_{\mathrm{BF}} & \mathbf{0} \\
\mathbf{K}_{\mathrm{FB}} & \mathbf{K}_{\mathrm{FF}} & \mathbf{K}_{\mathrm{FC}} \\
\mathbf{0} & \mathbf{K}_{\mathrm{CF}} & \mathbf{K}_{\mathrm{CC}}
\end{array}\right] \cdot\left[\begin{array}{l}
\mathbf{q}_{\mathrm{B}} \\
\mathbf{q}_{\mathrm{F}} \\
\mathbf{q}_{\mathrm{C}}
\end{array}\right]=\mathbf{p}
$$

where: $\mathbf{K}_{\mathrm{BB}}, \mathbf{K}_{\mathrm{FF}}, \mathbf{K}_{\mathrm{CC}}$-stiffness matrices of subsystems $\mathbf{B}, \mathbf{F}$, $\mathbf{C} ; \mathbf{K}_{\mathrm{BF}}, \mathbf{K}_{\mathrm{FB}}, \mathbf{K}_{\mathrm{FC}}, \mathbf{K}_{\mathrm{CF}}-$ matrices of elastic couplings among subsystems $\mathbf{B}, \mathbf{F}, \mathbf{C} ; \mathbf{q}_{\mathrm{B}}, \mathbf{q}_{\mathrm{F}}, \mathbf{q}_{\mathrm{C}}$ - displacements vectors of elements of subsystems $\mathbf{B}, \mathbf{F}, \mathbf{C}$.

On the grounds of so defined model of the multi-bolted connection, bolt forces, both during the joint assembly and after it has been completed can be evaluated.

The assembly process is an iterative process, which is composed of $k$ steps, in pursuance of the number of bolts in the connection. During the first bolt tightening, the system is made up of a joined element resting on a linear elastic foundation. In this first step, the system is loaded only by the force $\mathrm{F}_{\mathrm{m} 1}$ which is the preload of the bolt No. 1 (Fig. 2a). At that time in the connection model only a single bolt is concluded which is preloaded as the first bolt.

In the next steps of the connection tightening (for $\mathrm{i}=2, \ldots, \mathrm{k}$ ), in a suitable place the next hybrid element is b)

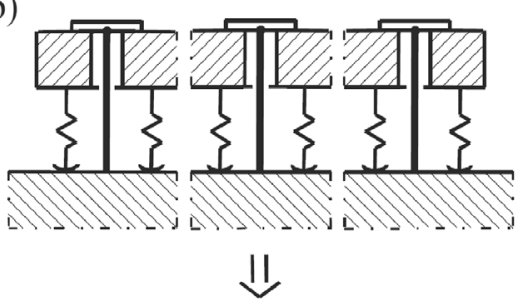

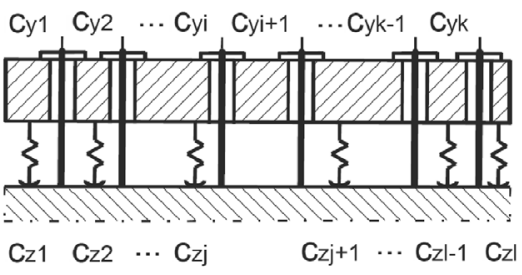

przemieszczeń uogólnionych; $\mathbf{p}$ wektor sił uogólnionych, zbudowany $\mathrm{z}$ sił napięcia wstępnego $\mathrm{F}_{\mathrm{mi}}$ (rys. 1c).

Sposób tworzenia macierzy sztywności K podano w pracy [7]. Przyjmując podział połączenia na trzy podukłady (B - zbiór śrub złącznych, F - model elementu łączonego, $\mathbf{C}$ warstwa stykowa), równanie równowagi (2) można przedstawić w postaci (3), gdzie: $\mathbf{K}_{\mathrm{BB}}, \mathbf{K}_{\mathrm{FF}}, \mathbf{K}_{\mathrm{CC}}$ - macierze sztywności podukładów $\mathbf{B}, \mathbf{F}, \mathbf{C} ; \mathbf{K}_{\mathrm{BF}}$, $\mathbf{K}_{\mathrm{FB}}, \mathbf{K}_{\mathrm{FC}}, \mathbf{K}_{\mathrm{CF}}-$ macierze sprzężeń sprężystych pomiędzy podukładami $\mathbf{B}, \mathbf{F}, \mathbf{C} ; \mathbf{q}_{\mathrm{B}}, \mathbf{q}_{\mathrm{F}}, \mathbf{q}_{\mathrm{C}}-$ wektory przemieszczeń uogólnionych podukładów $\mathbf{B}, \mathbf{F}, \mathbf{C}$.

Na podstawie tak zdefiniowanego modelu połączenia wielośrubowego możliwe jest wyznaczenie wartości sił w śrubach w czasie montażu złącza i po jego zakończeniu.

Proces montażu połączenia jest procesem iteracyjnym, złożonym z k kroków, odpowiednio do liczby śrub wchodzących w skład połączenia. Podczas napinania pierwszej śruby układ złożony jest z podatnego kołnierza posadowionego na liniowym modelu warstwy stykowej i obciążonego siłą napięcia wstępnego pierwszej śruby $\mathrm{F}_{\mathrm{m} 1}$ (rys. 2a). Wówczas w połączeniu uwzględnia się tylko jeden model śruby (napinanej jako pierwsza).

W kolejnych krokach napinania $(\mathrm{dla} i=2, \ldots, k)$, w odpowiednim miejscu, dodaje się następny model śruby i tym samym macierz sztywności zbioru śrub złącznych $\mathbf{K}_{\mathrm{BB}}$ zostaje rozbudowana o kolejne elementy odpowiadające śrubom napinanym w danym kroku.

W wyniku rozwiązania układu równań (3) otrzymuje się odpowiednie składowe wektora przemieszczeń uogólnionych $\mathbf{q}_{\mathrm{B}}$ (4).

Końcowe odkształcenia śrub $\mathrm{q}_{\mathrm{Bi}} \mathrm{w}$ danym kroku napinania połączenia wyznacza się na podstawie rysunku 3a od punktów $\mathrm{P}_{\mathrm{i}}$ ' określających stan napięcia śrub w poprzednim kroku obliczeń. Tak zdefiniowanym odkształceniom $\mathrm{q}_{\mathrm{Bi}}$ odpowiadają siły w śrubach $\mathrm{F}_{\mathrm{mi}}$ obliczane na podstawie zależności (5).
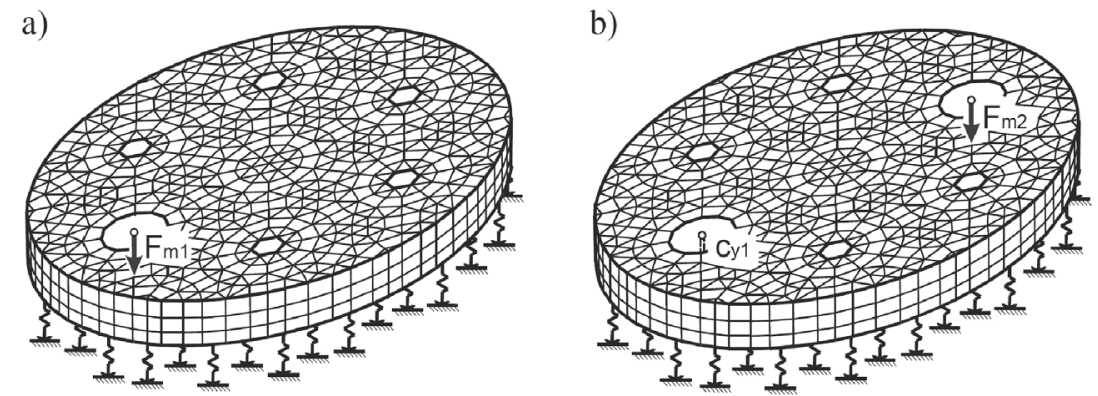

Fig. 2. Start of the assembly process: a) preloading of the first bolt, b) preloading of the second bolt Rys. 2. Początek procesu montażu: a) napinanie pierwszej śruby, b) napinanie drugiej śruby 
taken into consideration. Therefore, the stiffness matrix of the bolts subsystem $\mathbf{K}_{\mathrm{BB}}$ complements with the elements corresponding to the bolts that are preloaded in the current step of the computations.

Upon solving the equation (3) we obtain the displacements vector of bolts $\mathbf{q}_{\mathrm{B}}$ :

$$
\mathbf{q}_{B}=\operatorname{col}\left(\mathrm{q}_{\mathrm{B} 1}, \mathrm{q}_{\mathrm{B} 2}, \ldots, \mathrm{q}_{\mathrm{Bi}}, \ldots, \mathrm{q}_{\mathrm{Bk}}\right)
$$

The final displacements of bolts $\mathrm{q}_{\mathrm{Bi}}$ in the current step of the connection tightening are measured from the working points $\mathrm{P}_{i}^{\prime}$ that determine the tension of bolts in the previous step of the calculations as shown in Figure 3a. On the grounds of so defined displacements $\mathrm{q}_{\mathrm{Bi}}$, the bolt forces $\mathrm{F}_{\mathrm{mi}}$ can be computed using the formula:

$$
\mathrm{F}_{\mathrm{mi}}=\mathrm{c}_{\mathrm{yi}} \cdot \mathrm{q}_{\mathrm{Bi}}
$$

Upon solving the equation (3) we also obtain the displacements vector of linear springs $\mathbf{q}_{\mathrm{C}}$ :

$$
\mathbf{q}_{\mathrm{C}}=\operatorname{col}\left(\mathrm{q}_{\mathrm{C} 1}, \mathrm{q}_{\mathrm{C} 2}, \ldots, \mathrm{q}_{\mathrm{Cj}}, \ldots, \mathrm{q}_{\mathrm{Cl}}\right)
$$

by means of which the tension of the contact layer after preloading the next bolt can be defined.

The final displacements of linear springs $\mathrm{q}_{\mathrm{Cj}}$ in the current step of the connection tightening are measured from the working points $\mathrm{P}_{\mathrm{j}}^{\prime}$ that determine the tension of the contact layer in the previous step of the calculations as shown in Figure $3 b$. On the grounds of so defined displacements $q_{C j}$, the forces $R_{m j}$ can be obtained from the relation (1) for $u_{j}$ equal to $\mathrm{q}_{\mathrm{Cj}}$.

\section{Results of multi-bolted connection calculations}

To generalize the problem under consideration, calculations of an asymmetrical multi-bolted connection shown in Figure $4 \mathrm{a}$ were carried out as an example. The connection is fastened using seven bolts M10x1.25. The adopted tightening sequence is parenthesized in Figure 4b.

The assumed connection is an element of the special test stand designed to measure the bolt forces in such a joint [9]. The calculations were carried out for the joined element thickness h equal to $20 \mathrm{~mm}$ and the preload of bolts $\mathrm{F}_{\text {mi }}$ equal to $20 \mathrm{kN}$. The stiffness characteristics of the linear springs is described by function:

$$
\mathrm{R}_{\mathrm{j}}=\mathrm{A}_{\mathrm{j}} \cdot\left(26.873 \cdot \mathrm{u}_{\mathrm{j}}\right)
$$

The results of the calculations were put together in graphs illustrated in Figures 5 and 6 . The variations of the forces in bolts during the assembly process are presented in Figure 5 following the scheme below:
W wyniku rozwiązania układu równań (3) otrzymuje się również odpowiednie składowe wektora przemieszczeń uogólnionych $\mathbf{q}_{\mathrm{C}}$ (6), za pomocą których definiuje się stan napięcia sprężyn liniowych warstwy stykowej po napięciu danej śruby.

Końcowe odkształcenia sprężyn liniowych $\mathrm{q}_{\mathrm{Cj}}$ w danym kroku napinania połączenia wyznacza się na podstawie rysunku 3 b od punktów $\mathrm{P}_{\mathrm{j}}^{\prime}$ określających stan napięcia elementów warstwy sprężystej w poprzednim kroku obliczeń. Odkształceniom $\mathrm{q}_{\mathrm{Cj}}$ odpowiadają siły $\mathrm{R}_{\mathrm{mj}}$, które można określić na podstawie charakterystyki (1) dla $\mathrm{u}_{\mathrm{j}}=\mathrm{q}_{\mathrm{Cj}}$. a)

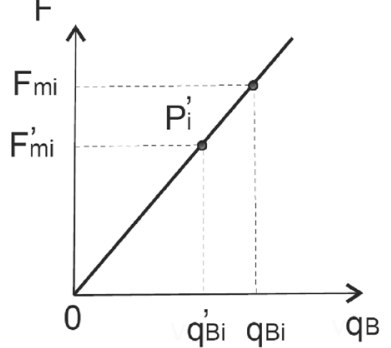

b)

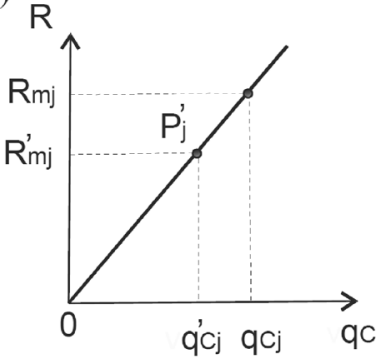

Fig. 3. Determining of the load: a) for bolts, b) for the contact layer Rys. 3. Określanie obciążenia: a) dla śrub, b) dla warstwy stykowej

\section{Wyniki obliczeń połączenia wielośrubowego}

Aby rozpatrywane zagadnienie cechowało się pewnym stopniem uogólnienia, jako przykład wykonano obliczenia niesymetrycznego połączenia wielośrubowego, pokazanego na rysunku 4a. Połączenie zaciskano za pomocą siedmiu śrub M10x1,25, według kolejności oznaczonej w nawiasach na rysunku $4 b$.

Przyjęte do obliczeń połączenie wielośrubowe jest elementem stanowiska laboratoryjnego zaprojektowanego do a)

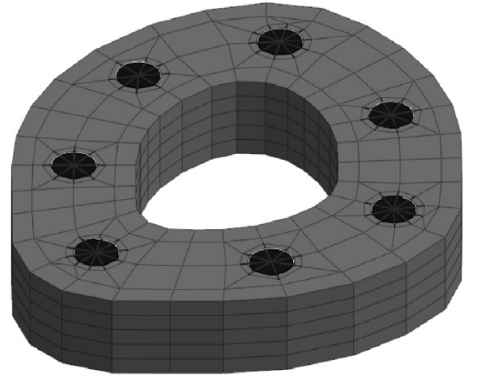

b)

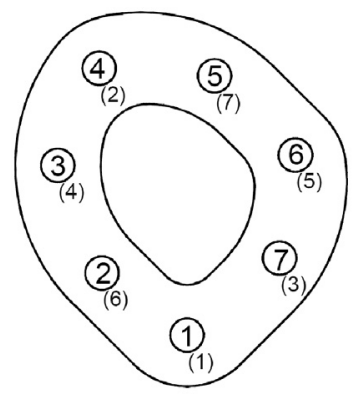

Fig. 4. Tested connection: a) simplified FE-model, b) contact surface Rys. 4. Badane połaczenie: a) uproszczony model MES, b) powierzchnia styku

pomiarów sił w tego typu złączu [9]. Obliczenia wykonano dla grubości kołnierza $\mathrm{h}=20 \mathrm{~mm}$ i napięcia wstępnego $\mathrm{F}_{\mathrm{mi}}=20$ kN. Charakterystyki sprężyn liniowych opisano funkcją (7).

Wyniki obliczeń zestawiono w formie wykresów pokazanych na rysunkach 5 i 6 . Na rysunku 5 przedstawiono przebiegi zmienności siły napięcia wstępnego w poszczególnych śrubach podczas montażu połączenia według następującego porządku: 
a) in the first line - the force changes in the bolt No. 1 (preloaded as the first bolt),

b) in the second line - the force changes in bolts No. 4 and 5 (preloaded as the second and the seventh bolt, respectively),

c) in the third line - the force changes in bolts No. 7 and 2 (preloaded as the third and the sixth bolt, respectively),

d) in the fourth line - the force changes in bolts No. 3 and 6 (preloaded as the fourth and the fifth bolt, respectively).

The scatter of the final bolt forces at the end of the assembly process is shown in Figure 6.

The computed preload values in individual bolts during the assembly process and after it has been completed are compared with their experimental values [9]. The adoption of the proposed model of the multi-bolted connection may cause a variation of preloads of the bolts during the assembly process from $-8.86 \%$ to $3.29 \%$.

The analysis of the relative difference between the obtained resulting preloads can be carried out on the basis of the $\mathrm{W}$ index defined by the formula:

$$
\mathrm{W}=\frac{\mathrm{F}_{\mathrm{mi}}^{\mathrm{FEM}}-\mathrm{F}_{\mathrm{mi}}^{\mathrm{EXP}}}{\mathrm{F}_{\mathrm{mi}}^{\mathrm{EXP}}} \cdot 100 \%
$$

where: $\mathrm{F}_{\mathrm{mi}}^{\mathrm{FEM}}$ - the force in the i-th bolt at the end of the assembly process according to the FEM model; $\mathrm{F}_{\mathrm{mi}}^{\mathrm{EXP}}-$ the force in the i-th bolt at the end of the assembly process according to experimental tests [9].

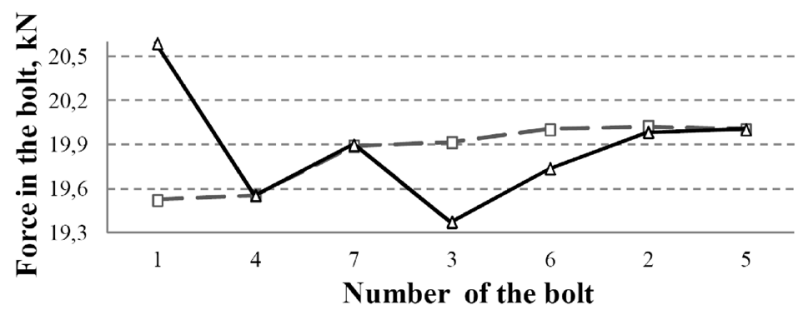

Fig. 6. Preload values at the end of the assembly process Rys. 6. Rozkład napięcia wstępnego śrub na koniec montażu połączenia

Table $1 . \mathrm{W}$ index values

Tabela 1. Wartości wskaźnika W

\begin{tabular}{|l|l|l|l|l|l|l|l|}
\hline $\mathrm{i}$ & 1 & 2 & 3 & 4 & 5 & 6 & 7 \\
\hline $\mathrm{W}, \%$ & -5.20 & 0.19 & 2.81 & -0.02 & 0 & 1.35 & -0.05 \\
\hline
\end{tabular}

W index values are set up in Table 1 . The adoption of the proposed model of the multi-bolted connection may bring on a variation of the resulting preloads of bolts from $-5.20 \%$ to $2.81 \%$.

\section{Conclusions}

In the case of preloaded multi-bolted connections, nonlinearity of the contact layer between the joined elements may have a negligible influence on the computational val- a) w rzędzie pierwszym - przebieg zmienności siły w śrubie nr 1 (napinanej jako śruba pierwsza),

b) w rzędzie drugim - przebiegi zmienności sił w śrubach o nr 4 i 5 (napinanych jako śruby druga i siódma),

c) w rzędzie trzecim - przebiegi zmienności sił w śrubach o nr 7 i 2 (napinanych jako śruby trzecia i szósta),

d) w rzędzie czwartym - przebiegi zmienności sił w śrubach o nr 3 i 6 (napinanych jako śruby czwarta i piąta).
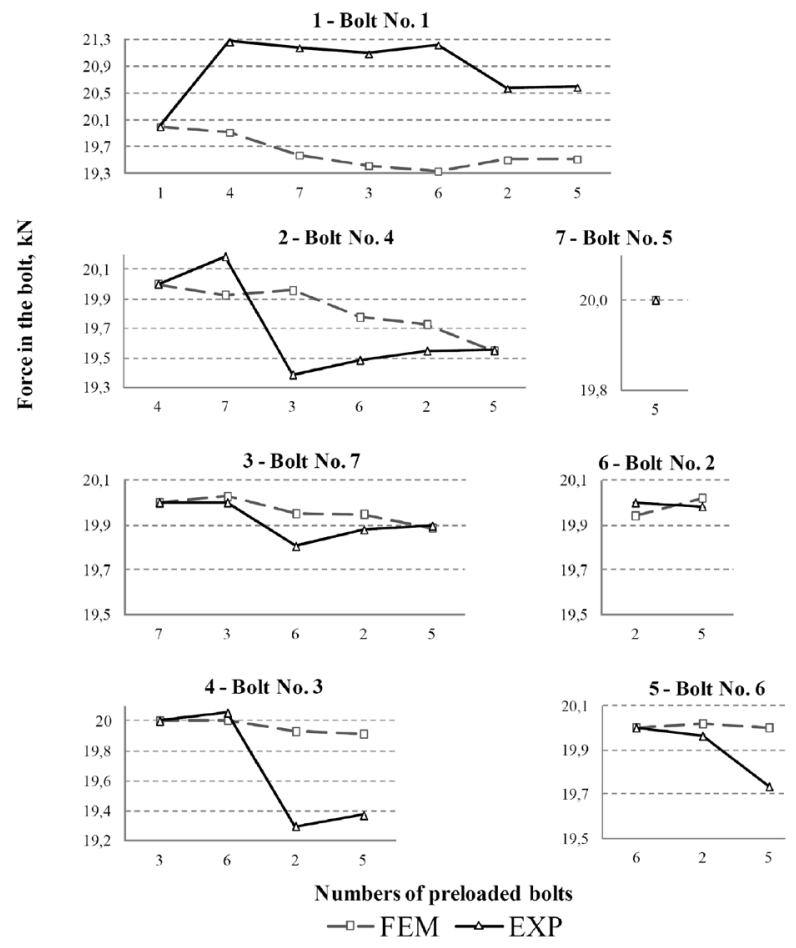

Fig. 5. Preload values during the assembly process

Rys. 5. Wartości napięcia wstępnego śrub podczas montażu połaczenia

Wykresy ostatecznych wartości sił w śrubach na koniec montażu pokazano na rysunku 6 .

Wartości napięcia wstępnego w śrubach w czasie procesu montażu i po jego zakończeniu wyznaczone dla modelu połączenia wielośrubowego porównano z wartościami uzyskanymi doświadczalnie [9]. Błąd obliczeń wartości napięcia wstępnego w czasie procesu montażu zmienia się od -8,86 \% do $3,29 \%$.

Ocenę względnej różnicy wartości końcowego napięcia wstępnego połączenia przeprowadzono na podstawie wskaźnika $\mathrm{W}$ określonego wzorem (8), gdzie: $\mathrm{F}_{\mathrm{mi}}^{\mathrm{FEM}}$ - napięcie wstępne i-tej śruby po montażu połączenia według modelu MES; $\mathrm{F}_{\mathrm{mi}}^{\mathrm{EXP}}$ - napięcie wstępne i-tej śruby po montażu połączenia uzyskane doświadczalnie [9].

Wartości wskaźnika W uzyskane dla poszczególnych śrub zestawiono w tabeli 1. Przyjęcie proponowanego modelu obliczeniowego połączenia wielośrubowego może powodować zmianę wartości wynikowego napięcia wstępnego śrub od $-5,20 \%$ do $2,81 \%$. 
ues of the bolt forces. Wherefore, for the calculations and analysis of such joints, linear models of the contact layer can be applied. Owing to this fact, one obtains a significantly higher efficiency of modeling, which is caused by both the smaller complexity of the problem and a considerably shorter process time.

The presented model of the multi-bolted connection can also allow an assessment of how the tightening sequence affects the preload values in the bolts before the preloaded joint is loaded by an external force.

\section{Wnioski}

Dla połączeń wielośrubowych napiętych wstępnie, nieliniowość warstwy stykowej między łączonymi elementami może mieć niewielki wpływ na wartości sił napięcia wstępnego w śrubach, dlatego w analizie tego typu połączeń zaleca się stosowanie liniowych modeli warstwy stykowej. Dzięki mniejszej wymiarowości zadania i krótszemu czasowi obliczeń uzyskuje się wówczas większą efektywność modelowania.

Przedstawiony model obliczeniowy umożliwia ocenę wpływu kolejności napinania śrub na wartości sił w śrubach przed przyłożeniem do układu siły eksploatacyjnej.

\section{Nomenclature/Oznaczenia}

B set of bolts/zbiór śrub

C linear Winkler model of the contact layer/liniowy model warstwy stykowej typu winklerowskiego
F joined element model/model elementu taczonego

FEM (MES) finite element method/metoda elementów skończonych

\section{Bibliography/Literatura}

[1] Adams V., Askenazi A. Building better products with Finite Element Analysis, Santa Fe, OnWord Press 1999.

[2] Chang C.-C., Wang Q.G. Modeling of bolt joint behavior of cast aluminum alloy (A380-T5) by coupling creep and plasticity in finite element analysis, Metallurgical and Materials Transactions B, 38(4), 2007, 607-613.

[3] Cho S.-S. et al. Assessment of an engine cylinder head-block joint using finite element analysis, International Journal of Automotive Technology, 11(1), 2010, 75-80.

[4] Chyuan S.-W. Finite element simulation of a twin-cam 16-valve cylinder structure, Finite Elements in Analysis and Design, 35(3), 2000, 199-212.

[5] Fontanesi S., Giacopini M. Multiphase CFD-CHT optimization of the cooling jacket and FEM analysis of the engine head of a V6 diesel engine, Applied Thermal Engineering, 52(2), 2013, 293-303.

[6] Griza S. et al. Fatigue in engine connecting rod bolt due to forming laps, Engineering Failure Analysis, 16(5), 2009, 1542-1548 .

[7] Grzejda R. Determination of bolt forces for the assembly condition of a bolted flange connection, Archives of Mechanical Technology and Automation, 33 (2), 2013, 3-12.

Rafał Grzejda, DEng. - doctor in the Faculty of Mechanical Engineering and Mechatronics at West Pomeranian University of Technology, Szczecin. Dr inż. Rafat Grzejda - adiunkt na Wydziale Inżynierii Mechanicznej i Mechatroniki w Zachodniopomorskim Uniwersytecie Technologicznym w Szczecinie. e-mail: rafal.grzejda@zut.edu.pl
[8] Grzejda R. FE-modeling of bolts in the flange joint assembling phase condition (in Polish), Mechanik, 87(8-9), 2014, 672675.

[9] Grzejda R. et al. Experimental investigations of an asymmetrical bolted connection loaded by an eccentric force (in Polish), Przegląd Mechaniczny, 71(1), 2012, 21-27.

[10] Kamiński T., Filipek P. Fiber optic, interferometric pressure sensor as source of information about an combustion process of internal combustion engine with spark ignition (in Polish), Eksploatacja i Niezawodność - Maintenance and Reliability, 2, 2003, 31-33.

[11] Kukla S., Szewczyk M. Free vibration of annular plates of stepped thickness resting on Winkler elastic foundation, Scientific Research of the Institute of Mathematics and Computer Science, 6(1), 2007, 109-116.

[12] Lee C.-C. et al. Design and analysis of gasket sealing of cylinder head under engine operation conditions, Finite Elements in Analysis and Design, 41(11-12), 2005, 1160-1174.

[13] Monieta J. Diagnostics of work process course in cylinders of marine reciprocating internal combustion engines using vibration signal, Combustion Engines, 3, 2013, 161-167.

[14] Over H.-H. et al. Web-enabled database for gasket parameters, Analysis of bolted joints, Proc. of the 2003 ASME Pressure Vessels and Piping Conference, ASME, Cleveland, 2003, $97-$ $-109$.

[15] Schaaf M., Bartonicek J. Calculation of bolted flange connections of floating and metal-to-metal contact type, Analysis of bolted joints, Proc. of the 2003 ASME Pressure Vessels and Piping Conference, ASME, Cleveland, 2003, 59-64.

[16] Sroka Z.J. Durability of engine components due to alternative fuels, Eksploatacja i Niezawodność - Maintenance and Reliability, 4, 2007, 9-15. 